\title{
The role of sports clubs in developing citizenship values to counter crime in Egyptian society.
}

\section{Dr. Amin Mahmoud Gaafar}

Lecturer, Sports Management and Recreation Department

Faculty of Physical Education for Men Alexandria University

\section{Introduction}

Sports clubs' role is no longer limited to achieve championships in all sports but exceeded to include security responsibility too, Sports institutions face riots and crimes of all kinds, e.g. "violence, drug use" that occur inside it; which will reflect negatively on the internal and external community of sports institution, therefore reducing crime phenomenon within the sports community carried out by many educational, sports and media institutions; We remember the crime of killing (73) martyrs in Port Said Stadium incident in Al-Masry and Al Ahli clubs match, which had a negative impact on Egyptian society, as a whole; therefore, sports clubs have an essential role in developing citizenship values i.e. loyalty and belonging, rights and duties and community participation to reduce crime within Egyptian society.

Hegazi (2002, p25) argues that sports clubs are the backbone of national sports sector in any country in the world, so any sports organization cannot harvest its fruit unless sports clubs are organized to the fullest possible extent, The sports club is no longer as the old sense, just a wide place for members for entertainment and wasting time, nor is it just a place includes a number of registered players in different sports federations ; their goal through practice is to get cups and medals, but sports club in our time has deeper mission, and greater target to achieve, it is like a school with programs and systems that share an active part with the rest of state institutions to work on young people education and youth care. Sport's club basic system bylaw define the club as "Sports Authority established according provisions of law No. 77 of the year 1975 the Club have to work to serve community in general and sports community in particular, and that in cooperation and solidarity with relevant sports and social organizations within the limits of state's public policy and the plan made by competent minister. (article 5). (Ministry of Youth and Sports, 2013)

The concept of security is one of the concepts with diverse significance, where this concept expands to include multiple contents which overlap in various life activities, it includes social reform, and link to judiciary and 
justice, education and counseling, security is a situation where human is protected or away from danger threatened. (Alosbae, 200, p10) (Muhanna, 1996, p. 22)

Security in contemporary society generally and in sports competitions particularly is no longer confined to police efforts and procedures, but has become an urgent need for concerted efforts of various community organizations to consolidate security base by Crime prevention and arrest outlaws. (www.ahram.org.eg/Al-Ahram-Files/News/128721.aspx, p1)

MacDonald (2003, p95) explains that citizenship is as set of practices that include political, civil, legal, cultural and educational practices, which formed over time as a result of social, political and intellectual movements.

The researcher believes that citizenship is a sense of belonging and loyalty to the country and political leadership, which is a source of fulfilling basic needs and self-protection from fateful dangers.

President Al-Sissi (2014) noted that we have begun the first steps to establish a modern civil state that respects the law, ensure opinion freedom for all, application citizenship and rule of law principles, and that region crises can be solved by applying citizenship principle and decisive confrontation of extremism forces. Egyptian national security is an integral part of worls national security.

The researcher believes in the importance of sports clubs to provide the right atmosphere to push the citizen to practice citizenship values to the fullest, because citizenship aims to work and achievement, which serves total development and public interest, enhances security in its total concept and foremost, follow the preventive measures and regulations aimed at strengthening public security and safety in all areas, perhaps the best way to reach this goal is concerted efforts of all citizenship parties i.e. citizen, state with all its security and civilian bodies, community with its multi institutions, so all are working under one umbrella, which is nation's higher interest, which aims to achieve a very sublime goal; human safety and protection from threat, fear or oppression source, ensure his dignity and freedom. Human is the fulcrum of the renaissance, development and reconstruction achievement, which is the goal of security and development in its total concept, and a way to achieve it at the same time.

\section{Research problem:}

What mentioned above illustrates the importance and necessity of citizenship concept in building and formation of cultural entity for any modern and advanced society, citizenship is no longer just a intellectually luxury or elite talk, citizenship became the cornerstone of building societies 
and modern and contemporary Nations, United States of America, despite its heavy reliance on multinational incoming to it, and although it consists of dissonant mix of multicultural and affiliations humans; but the existence of citizenship principle and relied entirely upon it in terms of that citizenship is the relationship between individual and the state characterized with abiding by the obligations, respect rights, equality, justice and sufficiency principles, eventually led to melt this mixture in one nation, all works for its renaissance and progress. European Union model, despite the multiplicity of peoples and disagreement in belonging, culture and language, but the relationship between them was based on the existing of good citizenship on the exchange of rights and duties and the right of participation and mutual respect, making Europe although it is, historically, a motley continent looks like one nation for all their children without discrimination or intolerance, and make the Europeans at the forefront of the world's people towards progress and prosperity, because building and formation of citizenship concept require use of all possible and available means (such as economic, cultural, cognitive development). and considering that sports clubs practiced sport activities is of the most important means of cognitive, educational and economic development, which in our time attracting the attention of all society segments, at a time of expanded sports media activity, resulting in an increase in public awareness, and an increase in concrete impact produced by sports in construction of community collective mind, as well as the impact on the individual personality styles, because of their special status among Egyptian society to refuse violence.

Moussa (2000) study results confirmed high practice of organizational citizenship aspects and behaviors within managers and teachers in primary schools, Qtaify (2002) study results noted the need to link school physical and sports activities programs with some important human events that reinforce citizenship principles among young people, whether international or national "such as celebration of World Human Rights Day, World peace Day," Eli \& Kirk (2002) study results assured the increase of volunteer work attractiveness and importance within sports youth leaders, which may be useful for sports organizations, educators and officials in local community, contributing to formation of a good citizen, Mark et.al (2008) study results noted) that sports practice work to reinforce good citizenship values and behavior; if sports practice values applied (work dedication - belonging to group - respect legitimacy of official decisions - leadership and dependency - integrity and honor - competition) in individuals lives as they are inside stadium, Podsakoff et.al (2009) study results confirmed that existence of organizational citizenship behavior among workers increase their 
assessment marks, and positively affect allocation of revenues. Based on this researcher believes that it is necessary to study the role of sports clubs in developing citizenship values to counter crime in Egyptian society to build a society preserves its culture and identity.

\section{Research objectives:}

The research aims at identify study the role of sports clubs in developing citizenship values to counter crime in Egyptian society by identifying:

1 - Sports clubs goals in citizenship values development within its members

2- Citizenship values within sports clubs members

3- Obstacles that limit the role of club programs in countering crime

4- Methods of activating the role of sports clubs programs in countering crime

\section{Research queries:}

1- What are the sports clubs goals in citizenship values development within its Members?

2- What are citizenship values available within sports clubs members?

3- What are the obstacles limit the role of club programs in countering crime?

4- What are the methods of activating the role of sports clubs programs in countering crime?

\section{Research Terms:}

\section{Citizenship:}

Britannica Encyclopedia defined citizenship as:

"The relationship between the individual and the state, as determined by that State law, including duties and rights in that state and implicitly indicate the degree of freedom with the attendant responsibilities." (Ghalioun, 1991, p5)

\section{Crime:}

Is a set of undesirable behavioral patterns and acts which are not in line with community standards. "Procedural definition"

\section{Research Procedures}

- Research Methodology: The researcher used descriptive approach due to its appropriateness of research nature.

- The research community: includes sports clubs board members, managers and members.

The research sample: (42) board members of "Al-Ahli, Zamalek, Etihad, Port said AIMasry, Smouha" clubs, and (433) members of these clubs

Data collection tools:

Researcher designed a questionnaire passing the following steps: 
- Conduct a survey of theoretical studies, scientific research and related references.

- Determine questionnaire's aspects as [er set objectives.

- Identify phrases vocabulary that reflect questionnaire's aspects.

- Presenting the initial questionnaire to (8) experts in sports management field to identify:

- Aspects appropriateness to research topic.

- Each aspect phrases suitability to its topic.

- Phrases adequacy, comprehensiveness and correlation.

Experts agreement on questionnaire final form were between 85\% and $100 \%$ after deleting and modifying each aspect's phrases according to experts opinions.

Questionnaire Validity and reliability:

I - Validity: Validity was assured using two methods namely:

a - Content validity: researchers relied on arbitrators validity to identify aspects and phrases appropriateness and clarity, where some phrases were deleted or modified according to experts' opinion.

B - Internal consistency validity: internal consistency has been assured by calculating correlation coefficients between phrases and its aspect's total marks as follows:

First aspect: - "Sports clubs goals in citizenship values development within members" internal consistency coefficient ranged between $(0.590$ to 0.802 ) which are significant at 0.01 level, which confirms that all aspect's phrases measure what is measured by the aspect and are therefore characterized by validity and measure what it designed to measure.

Second aspect - "sports clubs and citizenship values within Members" internal consistency coefficient ranged between $(0.542$ to 0.760 ) which are significant at 0.01 level, which confirms that all aspect's phrases measure what is measured by the aspect and are therefore characterized by validity and measure what it designed to measure.

Third aspect - "obstacles that limit the role of sports clubs programs in countering crime" internal consistency coefficient ranged between (0.513 to 0.774) which are significant at 0.01 level, which confirms that all aspect's phrases measure what is measured by the aspect and are therefore characterized by validity and measure what it designed to measure.

Fourth aspect: - " Methods of activating the role of sports clubs programs in countering crime" internal consistency coefficient ranged between (0.517 to 0.811 ) which are significant at 0.01 level, which confirms 
that all aspect's phrases measure what is measured by the aspect and are therefore characterized by validity and measure what it designed to measure

II- Reliability : was assured using two methods namely

a- Questionnaire administration / re-administration method:

The researcher administrated the questionnaire to randomly selected (37) subjects from research community and not included in main research sample on July $7^{\text {th }}, 2014$, and then re-administrated the questionnaire after 15 days on July $7^{\text {th }}, 2014, T$ test values between the two administrations were calculated and ranged between (0.50 and 1.06) which is not significant at 0.05 level, while correlation (reliability) coefficient between the two administrations for all aspects ranged between (0.89 and 0.95), which indicates high questionnaire reliability.

\section{b- Alpha reliability coefficient for Kronbach}

This coefficient is an indicator of equality and give minimum estimated reliability coefficient values, i.e. general reliability coefficient never less than alpha coefficient alpha Kronbach reliability coefficient ranged between (0.7870 and 0.8222) which is significant ay a0.01, which proof questionnaire'.

Main study: main study was conducted in the period from July $21^{\text {th }}$ to September $3^{\text {rd }}, 2014$. 03/09/2014. 
First aspect Presentation and discussion:

Table (1) differences between (board members and managers) group and (members) group in approval percentage for first aspect: Sports clubs goals in citizenship values development within members

\begin{tabular}{|c|c|c|c|c|c|}
\hline \multirow[b]{2}{*}{$\begin{array}{c}\text { Phrase } \\
\text { No }\end{array}$} & \multirow[b]{2}{*}{ phrases content } & \multicolumn{2}{|c|}{$\begin{array}{c}\text { approval percentage } \\
\text { (Relative } \\
\text { percentage) }\end{array}$} & \multirow[b]{2}{*}{$\begin{array}{c}\text { Difference } \\
\text { between } \\
\text { percentages }\end{array}$} & \multirow[b]{2}{*}{$\begin{array}{l}\text { Chi } \\
\text { square }\end{array}$} \\
\hline & & $\begin{array}{c}\text { clubs } \\
\text { Board } \\
\text { members } \\
\text { and } \\
\text { managers }\end{array}$ & Members & & \\
\hline 1 & $\begin{array}{l}\text { Composition of } \\
\text { youth integrated } \\
\text { personality } \\
\text { respects: - }\end{array}$ & & & & \\
\hline $1 \mathrm{a}$ & Social & 93.53 & 93.62 & 0.09 & 0.00 \\
\hline $1 \mathrm{~b}$ & Health & 95.38 & 91.49 & 3.89 & 0.08 \\
\hline $1 \mathrm{c}$ & Religious & 88.11 & 95.74 & 7.63 & 0.32 \\
\hline $1 \mathrm{~d}$ & $\begin{array}{l}\text { Psychological } \\
\text { and intellectual }\end{array}$ & 90.99 & 92.55 & 1.56 & 0.01 \\
\hline $1 \mathrm{H}$ & Recreational & 89.72 & 95.74 & 6.02 & 0.20 \\
\hline 2 & $\begin{array}{ll}\text { SPREAD } & \text { sports } \\
\text { and } & \text { social } \\
\text { education } & \end{array}$ & 88.34 & 94.68 & 6.34 & 0.22 \\
\hline 3 & $\begin{array}{l}\text { Broadcast } \\
\text { national spirit } \\
\text { among members }\end{array}$ & 89.72 & 90.43 & 0.71 & 0.00 \\
\hline 4 & $\begin{array}{l}\text { Spread } \\
\text { cooperation and } \\
\text { harmony spirit } \\
\text { among members }\end{array}$ & 93.3 & 89.36 & 3.94 & 0.08 \\
\hline 5 & $\begin{array}{l}\text { Provide } \\
\text { conditions } \\
\text { necessary to } \\
\text { invest leisure } \\
\text { time by: - }\end{array}$ & & & & \\
\hline $5 \mathrm{~A}$ & $\begin{array}{ll}\text { Varied } & \text { sports } \\
\text { activities } & \end{array}$ & 90.76 & 93.62 & 2.86 & 0.04 \\
\hline
\end{tabular}




\begin{tabular}{|c|c|c|c|c|c|}
\hline $5 \mathrm{~b}$ & $\begin{array}{l}\text { Cultural activities } \\
\text { "literary } \\
\text { meetings, plays } \\
\text { and other" }\end{array}$ & 94.69 & 94.68 & 0.01 & 0.00 \\
\hline $5 c$ & $\begin{array}{l}\text { Group activities } \\
\text { "summer camps, } \\
\text { scout activities, } \\
\text { recreational } \\
\text { trips" }\end{array}$ & 89.38 & 93.62 & 4.24 & 0.10 \\
\hline 6 & $\begin{array}{l}\text { Investment youth } \\
\text { power in } \\
\text { community } \\
\text { service projects } \\
\text { and environment } \\
\text { development }\end{array}$ & 93.76 & 95.74 & 1.98 & 0.02 \\
\hline 7 & $\begin{array}{l}\text { Acquisition of } \\
\text { behavioral and } \\
\text { moral values and } \\
\text { delinquency } \\
\text { prevention }\end{array}$ & 94.69 & 93.62 & 1.07 & 0.01 \\
\hline 8 & $\begin{array}{l}\text { Acquisition and } \\
\text { development of } \\
\text { physical health } \\
\text { and abilities and } \\
\text { talent } \\
\text { development }\end{array}$ & 90.53 & 94.68 & 4.15 & 0.09 \\
\hline 9 & $\begin{array}{l}\text { Provide } \\
\text { participation } \\
\text { opportunities for } \\
\text { club members in } \\
\text { programs and } \\
\text { educational } \\
\text { activities that are } \\
\text { offered to them } \\
\text { to satisfy their } \\
\text { preferences for } \\
\text { these } \\
\text { educational and } \\
\text { hobbies activities }\end{array}$ & 96.77 & 92.55 & 4.22 & 0.09 \\
\hline 10 & Support sports & 92.15 & 96.81 & 4.66 & 0.11 \\
\hline
\end{tabular}




\begin{tabular}{|c|c|c|c|c|c|}
\hline & $\begin{array}{l}\text { for all programs } \\
\text { and create closer } \\
\text { links between } \\
\text { clubs and } \\
\text { families and give } \\
\text { discounts for } \\
\text { those who wish } \\
\text { to obtain } \\
\text { membership }\end{array}$ & & & & \\
\hline 11 & $\begin{array}{lr}\text { Support religious } \\
\text { activities } & \text { in } \\
\text { sports } & \text { clubs } \\
\text { programs } \\
\text { through } \\
\text { seminars } \\
\text { lectures and } \\
\text { establish to } \\
\text { meaning of the } \\
\text { Islamic faith and } \\
\text { ideals in youth } \\
\text { concepts. }\end{array}$ & 88.91 & $\begin{array}{l}96.81 \\
\text { concepts }\end{array}$ & 7.90 & 0.34 \\
\hline 12 & $\begin{array}{l}\text { Educate parents } \\
\text { with low } \\
\text { educational level } \\
\text { to highlight the } \\
\text { importance of } \\
\text { clubs to } \\
\text { strengthen their } \\
\text { children's future } \\
\text { intellectually and } \\
\text { physically }\end{array}$ & 89.15 & 96.81 & 7.66 & 0.32 \\
\hline 13 & $\begin{array}{l}\text { Conduct sports } \\
\text { and cultural } \\
\text { competitions } \\
\text { between schools } \\
\text { and sports clubs } \\
\text { to link clubs } \\
\text { programs with } \\
\text { schools } \\
\text { programs so that }\end{array}$ & 91.69 & 94.68 & 2.99 & 0.05 \\
\hline
\end{tabular}




\begin{tabular}{|c|c|c|c|c|c|}
\hline & $\begin{array}{l}\text { youth be in } \\
\text { useful programs } \\
\text { during the period } \\
\text { of his leisure } \\
\text { time after leaving } \\
\text { school }\end{array}$ & & & & \\
\hline 14 & $\begin{array}{lr}\text { Increase } & \text { national } \\
\text { and } & \text { security } \\
\text { sense } & \text { within } \\
\text { youth. } & \end{array}$ & 73.67 & 94.68 & 21.01 & 2.62 \\
\hline 15 & $\begin{array}{l}\text { Conduct courses } \\
\text { in intellectual } \\
\text { security to } \\
\text { counter crimes in } \\
\text { sports clubs }\end{array}$ & 89.84 & 94.68 & 4.84 & 0.13 \\
\hline
\end{tabular}

${ }^{*}$ Chi square significant at $0.05=3.84$

Table (1) results revealed that there is no statistically significant differences between (members) and (board member and managers) groups in approval percentage for first aspect: Sports clubs goals in citizenship values development within members; as chi square values ranged between ( 0.00 to 2.62), which are not significant at the 0.05 level.

In this regard Elsabea (2005, p4) notes that sports clubs are from educational institutions, which play an important and influential role in citizens guiding, caring, and fill their leisure time in a manner which works to achieve the desired objectives. Those clubs management interested to achieve their educational mission in light of the overall objectives established by state for youth care and formation of social, health, religious and intellectual integrated personality through spreading physical and social education, transmit national spirit among club members and various talents development.

Abo-Sheashea (2005, p7) argues that The sports club is no longer as the old sense, just a wide place for members for entertainment and wasting time, nor is it just a place includes a number of registered players in different sports federations ; their goal through practice is to get cups and medals, but sports club in our time has deeper mission, and greater target to achieve, it is like a school with programs and systems that share an active part with the rest of state institutions to work on young people education and youth care. 
Behbehani (2004, p39) explains that club was and still plays an important role in individuals and communities live in various kinds and levels.)

Abdel-Moez $(1996$, pp90, 96) noted that the club is not of innovative things in this age, but club existence associated with human presence and living anywhere and it is not known exactly when, where and how first club in history established, as it is associated with human appearance on earth since millions of years, club concept has been associated with human need of recreation and therefore physical needs as a core activity and irreplaceable social activity as sport is a social phenomenon.

Mustafa (2002, pp69-70), Derwish and Abdel-Moez (2000, p53)confirmed the importance of sports club and it is, almost, the only one that offers full and varied services to its members of all categories and various ages as an important segment of society, and most important of these services "connect all the programs to general religious national objectives, give young people sufficient awareness and deep sense of society problems and believe in positive contribution to discuss these problems and work to find appropriate solutions, compose sports teams in various activities and care in all respects, work for the club to be an educational institution plays an active role in formation of youth generations more aware and more solid, preparing youth to help them setup their role in serving the nation.

Through the above researcher believes that sports clubs youth, which seek to achieve are youth care and formation of a good citizen who is capable to serve religion, nation protect, and stay away from crime and delinquency in all forms, especially in this era in which deviant thoughts spread. That is to be achieved through provision of meaningful and useful p. 
Second aspect Presentation and discussion:

Table (2) differences between (board members and managers) group and (members) group in approval percentage for second aspect: sports clubs and citizenship values within members

\begin{tabular}{|c|c|c|c|c|c|}
\hline \multirow[b]{2}{*}{$\begin{array}{c}\text { Phrase } \\
\text { No }\end{array}$} & \multirow[b]{2}{*}{$\begin{array}{l}\text { phrases } \\
\text { content }\end{array}$} & \multicolumn{2}{|c|}{$\begin{array}{c}\text { approval percentage } \\
\text { (Relative } \\
\text { percentage) } \\
\end{array}$} & \multirow[b]{2}{*}{$\begin{array}{c}\text { Difference } \\
\text { between } \\
\text { percentages }\end{array}$} & \multirow[b]{2}{*}{$\begin{array}{l}\text { Chi } \\
\text { square }\end{array}$} \\
\hline & & $\begin{array}{l}\text { clubs } \\
\text { Board } \\
\text { members } \\
\text { and } \\
\text { managers }\end{array}$ & Members & & \\
\hline A & \multicolumn{5}{|c|}{$\begin{array}{l}\text { Belonging: is an internal feeling makes citizen enthusiasm } \\
\text { and sincerity works to improve homeland and defend it," } \\
\text { within requirements of belonging that individual feel proud } \\
\text { with country, defend it and concern for its safety, belonging } \\
\text { could be achieved through }\end{array}$} \\
\hline 1 & $\begin{array}{l}\text { Receiving } \\
\text { teams wherts } \\
\text { returning from } \\
\text { tournaments }\end{array}$ & 94.11 & \begin{tabular}{|l|}
80.85 \\
\end{tabular} & 13.26 & 1.00 \\
\hline 2 & $\begin{array}{l}\text { follow sporting } \\
\text { events and news } \\
\text { for sports club } \\
\text { difference }\end{array}$ & 91.45 & 100 & 8.55 & 0.38 \\
\hline 3 & $\begin{array}{l}\text { support teams in } \\
\text { all } \\
\text { leagues }\end{array}$ & 95.73 & 73.4 & 22.33 & 2.95 \\
\hline 4 & $\begin{array}{l}\text { Raise Egyptian } \\
\text { flag at the club } \\
\text { when winning } \\
\text { sports } \\
\text { championships }\end{array}$ & 63.86 & 68.09 & 4.23 & 0.14 \\
\hline 5 & $\begin{array}{l}\text { Publish sports } \\
\text { teams' } \\
\text { achievements }\end{array}$ & 91.69 & 91.49 & 0.20 & 0.00 \\
\hline B & \multicolumn{5}{|c|}{$\begin{array}{l}\text { Rights: The concept of citizenship, includes rights enjoyed } \\
\text { by all citizens and it is at the same time, the state and society } \\
\text { duties, including ( provision of education, health care } \\
\text { delivery, justice and equality, opinion, believe and }\end{array}$} \\
\hline
\end{tabular}




\begin{tabular}{|c|c|c|c|c|c|}
\hline & \multicolumn{5}{|c|}{$\begin{array}{l}\text { ownership freedom). These rights should be enjoyed by all } \\
\text { citizens without exception, whether they are residing within } \\
\text { the borders of the country or abroad, freedom principle could } \\
\text { be achieved by: }\end{array}$} \\
\hline 6 & $\begin{array}{l}\text { Practicing sport } \\
\text { as a fundamental } \\
\text { right for every } \\
\text { individual in the } \\
\text { community }\end{array}$ & 83.26 & 94.68 & 11.42 & 0.73 \\
\hline 7 & $\begin{array}{l}\text { Providing } \\
\text { monthly sports } \\
\text { programs for all } \\
\text { members }\end{array}$ & 77.37 & 93.62 & 16.25 & 1.54 \\
\hline 8 & $\begin{array}{lr}\text { Club } & \text { offers } \\
\text { financial support } \\
\text { necessary } & \text { for } \\
\text { practicing } & \\
\text { various } & \text { sports } \\
\text { activities } & \text { for } \\
\text { members } & \\
\end{array}$ & 90.42 & 95.74 & 5.32 & 0.15 \\
\hline 9 & $\begin{array}{l}\text { Providing sports } \\
\text { activities for } \\
\text { handicapped } \\
\text { individuals }\end{array}$ & 77.02 & 73.4 & 3.62 & 0.09 \\
\hline 10 & $\begin{array}{lr}\text { Provide } & \\
\text { educational } & \\
\text { seminars } & \text { to } \\
\text { illustrate } & \text { sport } \\
\text { importance } & \text { for } \\
\text { individual } & \text { and } \\
\text { society } & \\
\end{array}$ & 87.3 & 85.11 & 2.19 & 0.03 \\
\hline $\mathrm{C}$ & \multicolumn{5}{|c|}{$\begin{array}{l}\text { Duties are the tasks duties must be performed by every } \\
\text { citizen according to his ability, citizen should be committed } \\
\text { to these duties and perform it sincerely to the fullest possible } \\
\text { extent. Countries differ from each other in the } \\
\text { responsibilities of citizenship depending on the underlying } \\
\text { philosophy of the state, some of citizen duties are agreed on } \\
\text { e.g. "system respect, not to be a nation betrayer, } \\
\text { preservation of public property, contributing to country } \\
\text { development and defend it.duties could be achieved by: }\end{array}$} \\
\hline 11 & Compliance to & 78.06 & 96.81 & 18.75 & 2.01 \\
\hline
\end{tabular}




\begin{tabular}{|c|c|c|c|c|c|}
\hline & $\begin{array}{l}\text { laws and rules } \\
\text { governing sports } \\
\text { activity }\end{array}$ & & & & \\
\hline 12 & $\begin{array}{l}\text { Legitimacy of } \\
\text { local and } \\
\text { international } \\
\text { sports } \\
\text { institutions' } \\
\text { decisions }\end{array}$ & 90.53 & 94.68 & 4.15 & 0.09 \\
\hline 13 & $\begin{array}{l}\text { Using legal } \\
\text { means to } \\
\text { express } \\
\text { objection to any } \\
\text { injustice faced. }\end{array}$ & 89.49 & 91.49 & 2.00 & 0.02 \\
\hline 14 & $\begin{array}{l}\text { Maintain sports } \\
\text { facilities } \\
\text { (stadiums } \\
\text { lounges ...) }\end{array}$ & 98.61 & 81.91 & 16.70 & 1.54 \\
\hline 15 & $\begin{array}{l}\text { Commitment } \\
\text { during matches } \\
\text { to observe } \\
\text { sportsmanship }\end{array}$ & 97 & 89.36 & 7.64 & 0.31 \\
\hline 16 & $\begin{array}{l}\text { Respect sports } \\
\text { practice values } \\
\text { and traditions of } \\
\text { in our eastern } \\
\text { society }\end{array}$ & 97.34 & 92.55 & 4.79 & 0.12 \\
\hline 17 & $\begin{array}{l}\text { Respect } \\
\text { referee's } \\
\text { decisions during } \\
\text { matches. }\end{array}$ & 96.77 & 91.49 & 5.28 & 0.15 \\
\hline 18 & $\begin{array}{l}\text { Maintain } \\
\text { stadiums sanctity } \\
\text { during sports } \\
\text { matches }\end{array}$ & 97.34 & 91.49 & 5.85 & 0.18 \\
\hline D & \multicolumn{5}{|c|}{$\begin{array}{l}\text { Community Participation: Within the most citizenshi } \\
\text { features that citizen to be involved in community work, an } \\
\text { most important of which volunteer work, every contributio } \\
\text { serve the nation, and consequent community interests } \\
\text { provide advice and assistance to citizens and officials, } \\
\text { embodies the true meaning of citizenship, citizenshi } \\
\text { principle could be achieved by }\end{array}$} \\
\hline
\end{tabular}




\begin{tabular}{|c|c|c|c|c|c|}
\hline 19 & \begin{tabular}{l}
\multicolumn{2}{l}{ Cooperation } \\
during sports \\
activities
\end{tabular} & 90.76 & 89.36 & 1.40 & 0.01 \\
\hline 20 & $\begin{array}{l}\text { Attend summer } \\
\text { camps annually } \\
\text { organized by the } \\
\text { club }\end{array}$ & 92.26 & 82.98 & 9.28 & 0.49 \\
\hline 21 & $\begin{array}{l}\text { Volunteering to } \\
\text { participate in } \\
\text { sporting events } \\
\text { organized by the } \\
\text { club }\end{array}$ & 89.84 & 75.53 & 14.31 & 1.24 \\
\hline 22 & $\begin{array}{l}\text { Encourage } \\
\text { members to } \\
\text { community } \\
\text { participation } \\
\text { through } \\
\text { volunteer work }\end{array}$ & 96.54 & 94.68 & 1.86 & 0.02 \\
\hline 23 & $\begin{array}{l}\text { Participation in } \\
\text { sports festivals } \\
\text { that are calling } \\
\text { for a charitable } \\
\text { goals }\end{array}$ & 96.88 & 93.62 & 3.26 & 0.06 \\
\hline 24 & $\begin{array}{l}\text { Educate viewers } \\
\text { of sports } \\
\text { competitions to } \\
\text { comply with } \\
\text { sports } \\
\text { competition } \\
\text { ethics. }\end{array}$ & 60.39 & 68.09 & 7.70 & 0.46 \\
\hline 25 & $\begin{array}{l}\text { Contribution in } \\
\text { spreading sports } \\
\text { awareness } \\
\text { among } \\
\text { community } \\
\text { members. }\end{array}$ & 84.3 & 84.04 & 0.26 & 0.00 \\
\hline 26 & $\begin{array}{l}\text { Believe that } \\
\text { sports practice } \\
\text { creates a kind of } \\
\text { coherence and } \\
\text { cohesion among } \\
\text { community }\end{array}$ & 61.43 & 65.96 & 4.53 & 0.16 \\
\hline
\end{tabular}


\begin{tabular}{l|l|l|l}
\hline members & & & \\
\hline * Chi square significant at $0.05=3.84$ & \\
Table (2) results revealed that there is no statistically significant
\end{tabular} differences between (members) and (board member and managers) groups in approval percentage for second aspect: sports clubs and citizenship values within members; as chi square values ranged between (0.00 to 2.95), which are not significant at the 0.05 level.

\section{A. Belonging}

indicates Abdul-Ghani (2014) indicates) that sport become in our present era a social cultural, economic and political phenomenon, attracts the attention of all society segments, and that at a time when media consumption of sports activity expanded, resulting in an increase in public awareness, and sometimes produce among practitioners ethics exceed the noble goal of self-ambition, what distinguished the sports in our country in recent years is the increasing demand for practice of various sports kinds, it become necessary for us to keep up with the steady development of high-level sport and which has become the industry requires significant investments in multiple areas .

Al-abd and Al-Nassar (2007) confirmed that encourage make individual feels pride, provision of basic needs, which makes him accepts nationalism, devotion and loyalty to homeland, and this is what has been achieved when Egypt won the African Nations Cup of, 2006, 2008.and 2010 respectively and perfect performance in Confederations 2010 Cup Championship

\section{B. Rights}

indicates, Rauf (2006, pp11-12) that citizenship is the "characteristic of citizen who enjoy rights and abide by the obligations imposed by belonging to nation", citizenship here is membership and equal participation in society, including the consequent rights and duties, which means that all the children living above the soil of the homeland are equal without any discrimination based on any arbitrary criteria such as: religion, color, or economic or political and intellectual opinion, Enjoying citizenship make series of rights and duties based on four pivotal values are: (Equality Freedom - participation - Corporate Social Responsibility).

Rights are mutual relationship aim at individual and state benefit, improve community conditions and develop it for better and these duties may be prescribed by law and therefore determined officially which may implied by citizen, so he committed with it, These duties are paying taxes to the state, obeying laws, and defend the state. (Brook, 2009, p54)

\section{C - Duties}


indicates Al-Najjar (1999, p85) mentions that Countries differ from each other in the responsibilities of citizenship depending on the underlying philosophy of the state, some countries see that the political participation in the elections is a national duty and others do not see that, some of citizen duties of which agreed on in the world are "system respect, not to be a nation betrayer, preservation of public property, contributing to country development and defend it. These duties must be performed by every citizen according to his ability, citizen should be committed to these duties and perform it sincerely to the fullest possible extent Al-Arabi $(2001$, p85) indicated that when talking about relationship between (democracy, and civil society) and (citizenship), that citizenship is a base of democracy and through them together state sovereign is completes, citizenship embodied in a set of political and social values.

Yassin (2004) in the opinion that is no citizenship unless there is a civil society and a set of rights and obligations (duties).

\section{D - Community Participation}

Leya (2007, p64) indicates that individuals must be turned from just nationals have rights to citizens have rights and duties, which lead to emergence of a strong membership link, stresses the importance of cooperation and participation between pillars of full citizenship (the citizen, the society and the state) on the basis of rights enjoyment and duties performance between these three pillars.

Khedr (2000, p64), in the opinion that community members contribution and their participation in the prevention of crime and other hazards and counter deviation phenomena is prior to the presence of security services itself, where the old traditional controls were the law controlling community members' behavior, and breaking these controls was a departure from the community customs, values and traditions, and thus this breaking were facing condemnation and disapproval from most community members.

\section{Third aspect Presentation and discussion:}

Table (3) differences between (board members and managers) group and (members) group in approval percentage for third aspect: Obstacles that limit the role of club programs in countering crime

\begin{tabular}{c|c|c|c|c|c}
\hline \multirow{2}{*}{$\begin{array}{c}\text { Phrase } \\
\text { No }\end{array}$} & \multirow{2}{*}{ phrases content } & \multicolumn{2}{|c|}{$\begin{array}{c}\text { approval percentage } \\
\text { (Relative } \\
\text { percentage) }\end{array}$} & $\begin{array}{c}\text { Difference } \\
\text { between } \\
\text { percentages }\end{array}$ & $\begin{array}{c}\text { Chi } \\
\text { square }\end{array}$ \\
\cline { 3 - 4 } & $\begin{array}{c}\text { clubs } \\
\text { Board }\end{array}$ & Members & & \\
\hline
\end{tabular}




\begin{tabular}{|c|c|c|c|c|c|}
\hline & & $\begin{array}{l}\text { members } \\
\text { and } \\
\text { managers }\end{array}$ & & & \\
\hline 1 & $\begin{array}{l}\text { Weakness and } \\
\text { lack of qualified } \\
\text { human resources } \\
\text { needed } \\
\text { implement the } \\
\text { necessary } \\
\text { programs to } \\
\text { protect against } \\
\text { crimes }\end{array}$ & 93.76 & 95.74 & 1.98 & 0.02 \\
\hline 2 & $\begin{array}{l}\text { lack of material } \\
\text { resources } \\
\text { needed to } \\
\text { implement } \\
\text { necessary } \\
\text { program for } \\
\text { crime prevention } \\
\text { at sports clubs }\end{array}$ & 95.03 & 93.62 & 1.41 & 0.01 \\
\hline 3 & $\begin{array}{l}\text { Weakness of } \\
\text { media coverage } \\
\text { of various } \\
\text { programs at } \\
\text { sports clubs }\end{array}$ & 95.38 & 92.55 & 2.83 & 0.04 \\
\hline 4 & $\begin{array}{l}\text { lack of } \\
\text { coordination and } \\
\text { cooperation } \\
\text { between sports } \\
\text { clubs and } \\
\text { Ministry of Youth } \\
\text { and Sports and } \\
\text { Ministry of } \\
\text { Information to } \\
\text { curb crimes at } \\
\text { sports clubs }\end{array}$ & 94.8 & 91.49 & 3.31 & 0.06 \\
\hline 5 & $\begin{array}{l}\text { Interest in sports } \\
\text { activities, } \\
\text { especially } \\
\text { football and }\end{array}$ & 94.11 & 90.43 & 3.68 & 0.07 \\
\hline
\end{tabular}




\begin{tabular}{|c|c|c|c|c|c|}
\hline & $\begin{array}{l}\text { neglecting other } \\
\text { various programs }\end{array}$ & & & & \\
\hline 6 & $\begin{array}{lr}\text { Some r parents } \\
\text { have convictions } \\
\text { that } \\
\text { participation youth } \\
\text { sports in } \\
\text { programs } & \text { clubs } \\
\text { useless } & \text { is } \\
\end{array}$ & 94.92 & 91.49 & 3.43 & 0.06 \\
\hline 7 & $\begin{array}{l}\text { Lack of some } \\
\text { clubs } \\
\text { management } \\
\text { interest with } \\
\text { programs, } \\
\text { especially } \\
\text { cultural and } \\
\text { social ones. }\end{array}$ & 93.53 & 90.43 & 3.10 & 0.05 \\
\hline 8 & $\begin{array}{l}\text { Presence of } \\
\text { legacy customs } \\
\text { and traditions } \\
\text { that convey a } \\
\text { bad image of } \\
\text { sports clubs }\end{array}$ & 94.11 & 89.36 & 4.75 & 0.12 \\
\hline 9 & $\begin{array}{l}\text { Lack of youth } \\
\text { participation in } \\
\text { program } \\
\text { planning led to } \\
\text { its weakness }\end{array}$ & 95.38 & 90.43 & 4.95 & 0.13 \\
\hline 10 & $\begin{array}{l}\text { No focusing on } \\
\text { programs that } \\
\text { satisfy mental } \\
\text { and physical } \\
\text { youth desires }\end{array}$ & 92.84 & 89.36 & 3.48 & 0.07 \\
\hline 11 & $\begin{array}{l}\text { Non-evaluation } \\
\text { of different } \\
\text { programs } \\
\text { efficiency }\end{array}$ & 91.34 & 93.62 & 2.28 & 0.03 \\
\hline 12 & $\begin{array}{lr}\text { Lack } & \text { of } \\
\text { incentives } & \text { for } \\
\text { activities } & \text { and }\end{array}$ & 94.23 & 95.74 & 1.51 & 0.01 \\
\hline
\end{tabular}




\begin{tabular}{l|l|l|l|l}
\hline & $\begin{array}{l}\text { programs } \\
\text { administrators or } \\
\text { supervisors. }\end{array}$ & & & \\
\hline 13 & $\begin{array}{l}\text { Non-availability } \\
\text { of suitable } \\
\text { facilities to } \\
\text { accommodate } \\
\text { youth in clubs } \\
\text { such as } \\
\text { "theaters, } \\
\text { stadiums " }\end{array}$ & & & \\
\hline
\end{tabular}

${ }^{*}$ Chi square significant at $0.05=3.84$

Table (3) results revealed that there is no statistically significant differences between (members) and (board member and managers) groups in approval percentage for third aspect:: : Obstacles that limit the role of club programs in countering crime, as chi square values ranged between $(0.00$ to 0.13$)$, which are not significant at the 0.05 level.

In this regard, the researcher believes that the obstacles that limit the role of sports clubs and programs to protect youth from the intellectual deviations in its entirety an obstacle to the achievement of sports clubs' objectives and for which they were established to embrace young people and occupy their time with useful, which is reflected in its ability to protect from deviation toward crimes and prevent them from falling in suspicious groups promote destructive thoughts and exploit youth enthusiasm and unawareness to achieve their goals.

The study sample responses confirmed that within the obstacles is the lack of material resources needed to implement necessary program to prevent crimes at sports clubs, Al-Mashari (2002) study results confirmed that financial aspects of any sports organization affect achieving their goals due to lack of resources, most important financial obstacles that limit sports clubs programs role in youth protecting from crime can be summarized as: , " lack of necessary financial resources for implementation of sports, cultural and social programs to promote intellectual security, high cost for necessary qualifying training programs to establish and follow-up sporting, cultural, social programs events, High wages and salaries for authors of sports and social programs.

The study sample responses agreed that within obstacles that Some parents have convictions that youth participation in sports clubs programs is useless, Al-Baz (2011) study confirmed that one of the obstacles of social participation fiving the state full responsibility for security 
maintenance and crime prevention, and the ambiguity of social participation concept.

The study sample responses confirmed that within the obstacles the weakness of media coverage of various programs at sports clubs , AlHassaniya (2005) study results confirmed that Satellite channels' programs limit values consolidation within youth.

Fourth aspect Presentation and discussion:

Table (4) differences between (board members and managers) group and (members) group in approval percentage for to fourth aspect:

Methods of activating the role of sports clubs programs in countering crime

\begin{tabular}{|c|c|c|c|c|c|}
\hline \multirow[b]{2}{*}{$\begin{array}{c}\text { Phrase } \\
\text { No }\end{array}$} & \multirow[b]{2}{*}{$\begin{array}{l}\text { phrases } \\
\text { content }\end{array}$} & \multicolumn{2}{|c|}{$\begin{array}{l}\text { approval percentage } \\
\text { (Relative percentage) }\end{array}$} & \multirow[b]{2}{*}{$\begin{array}{l}\text { Difference } \\
\text { between } \\
\text { percentages }\end{array}$} & \multirow[b]{2}{*}{$\begin{array}{l}\text { Chi } \\
\text { square }\end{array}$} \\
\hline & & $\begin{array}{c}\text { clubs } \\
\text { Board } \\
\text { members } \\
\text { and } \\
\text { managers }\end{array}$ & Members & & \\
\hline 1 & $\begin{array}{ll}\text { Provide } & \text { the } \\
\text { necessary } & \\
\text { financial } & \\
\text { resources } & \text { to } \\
\text { implement } \\
\text { necessary } \\
\text { programs for } \\
\text { crime prevention }\end{array}$ & 98.61 & 90.43 & 8.18 & 0.35 \\
\hline 2 & $\begin{array}{l}\text { Coordination } \\
\text { between Ministry } \\
\text { of Youth and } \\
\text { Sports, sports } \\
\text { clubs and } \\
\text { educational } \\
\text { institutions to } \\
\text { consolidate } \\
\text { moderation }\end{array}$ & 94.92 & 93.62 & 1.30 & 0.01 \\
\hline 3 & $\begin{array}{l}\text { Manipulating } \\
\text { media through } \\
\text { development of }\end{array}$ & 94.92 & 85.11 & 9.81 & 0.53 \\
\hline
\end{tabular}




\begin{tabular}{|c|c|c|c|c|c|}
\hline & $\begin{array}{l}\text { programs which } \\
\text { refute imported } \\
\text { ideas and } \\
\text { suspicious } \\
\text { cultures }\end{array}$ & & & & \\
\hline 4 & $\begin{array}{l}\text { Expansion of } \\
\text { conducting } \\
\text { different } \\
\text { programs under } \\
\text { the slogan (no } \\
\text { for crime) }\end{array}$ & 95.15 & 92.55 & 2.60 & 0.04 \\
\hline 5 & $\begin{array}{l}\text { Calling famous } \\
\text { persons like } \\
\text { "scholars, } \\
\text { preachers, } \\
\text { writers, } \\
\text { celebrities foot } \\
\text { ball " in football }\end{array}$ & 96.3 & 88.3 & 8.00 & 0.35 \\
\hline 6 & $\begin{array}{lr}\text { Make } & \\
\text { motivational } & \\
\text { prizes } & \text { for } \\
\text { participants } & \text { in } \\
\text { various } & \\
\text { programs } & \text { and } \\
\text { activities } & \end{array}$ & 97.46 & 89.36 & 8.10 & 0.35 \\
\hline 7 & $\begin{array}{l}\text { Showing the } \\
\text { efforts made by } \\
\text { clubs in all its } \\
\text { programs and } \\
\text { cover it at all } \\
\text { media }\end{array}$ & 97.46 & 87.23 & 10.23 & 0.57 \\
\hline 8 & $\begin{array}{l}\text { Getting help of } \\
\text { youth care } \\
\text { programs } \\
\text { specialists in } \\
\text { reducing crime } \\
\text { programs }\end{array}$ & 95.96 & 89.36 & 6.60 & 0.24 \\
\hline 9 & $\begin{array}{lr}\text { Study } & \text { youth } \\
\text { needs } & \text { and } \\
\text { desires } & \text { between }\end{array}$ & 97.92 & 91.49 & 6.43 & 0.22 \\
\hline
\end{tabular}




\begin{tabular}{|c|c|c|c|c|c|}
\hline & sports clubs & & & & \\
\hline 10 & $\begin{array}{l}\text { Benefit from } \\
\text { other countries } \\
\text { experiences in } \\
\text { development } \\
\text { clubs programs } \\
\text { to reduce crime }\end{array}$ & 97.23 & 93.62 & 3.61 & 0.07 \\
\hline 11 & $\begin{array}{l}\text { activating the } \\
\text { role of media } \\
\text { center in clubs to } \\
\text { show club } \\
\text { programs in } \\
\text { crime protection } \\
\text { and reducing, } \\
\text { "extremism - } \\
\text { Intellectual } \\
\text { deviations" }\end{array}$ & 96.77 & 86.17 & 10.60 & 0.61 \\
\hline 12 & $\begin{array}{l}\text { Conducting } \\
\text { summer centers } \\
\text { programs at } \\
\text { activity stops } \\
\text { time to exploit } \\
\text { the potential of } \\
\text { clubs to curb } \\
\text { crime }\end{array}$ & 97.69 & 89.36 & 8.33 & 0.37 \\
\hline 13 & $\begin{array}{l}\text { exploitation of } \\
\text { famous players } \\
\text { celebrity players } \\
\text { in the awareness } \\
\text { programs for } \\
\text { crime protection } \\
\text { and reduction }\end{array}$ & 97.34 & 87.23 & 10.11 & 0.55 \\
\hline
\end{tabular}

* Chi square significant at $0.05=3.84$

Table (4) results revealed that there is no statistically significant differences between (members) and (board member and managers) groups in approval percentage for to fourth aspect: Methods of activating the role of sports clubs programs in countering crime, as chi square values ranged between ( 0.00 to 0.61 ), which are not significant at the 0.05 level.

The role of community addressing leisure time problem could be achieved through establishment of clubs, scientific and cultural museums 
and centers which explore talented youth and develop abilities and provide suitable places to practice hobbies and fill leisure time, individually or in a group with good members have sound thought, beliefs and behavior in a way which achieve youth ultimate success to serve their religion and their country.

Al-Khatib (2006, p53) argues that team loyalty development as a mean to develop homeland loyalty, is more than the role of sports programs in leisure time and activity renewal, but it extends to loyalty to one team which push for make effort in order to win over others, and this calls to win with merit, meaning instill principles to win with merit, not authoritarianism on others, and imposition an opinion on them by force, and use of violence to overcome them, this trend is that which entrenches intellectual security, through free will in accordance with Islam principles, which calls for moderation, renounces oppression and injustice.

AljAhni (2000, p217) explains that the objective of sports programs establishment is to establish public awareness raises morale and material sprit and comply with instructions and regulations that ensure individual's safety and security in various life fields, resulting in consolidating and deepening cooperation and respond to state various sectors to serve security and stability, which requires the mobilization of general feeling of participation importance in resisting the negative phenomena and support positive ones through specialized broadcast media which aims to spreading knowledge among community members and provide them with everything new in their specialization through lectures, seminars, speeches and all available means to ensure preparing them and sophisticating their interests to better performance of duties and tasks related to them, as the programs responsibility in the first place is to try to create a suitable environment, and identify views and attitudes and build an bridges of advice and mutual understanding through deepening national feeling of development importance, and it is shared responsibility require cooperation among all citizens to trap negative phenomena and reduce its effects.

Al-Otaibi (1994) study results confirmed the need for giving attention to broadcast information about programs offered by clubs and how to benefit from it.

\section{Conclusions:}

From results presentation and discussion the following were concluded:

First aspect: - "Sports clubs goals in citizenship values development within members" 
Research sample agreed that club goals which help to develop citizenship values within members, which represents a slice of the community to reduce crime where they are working to compose youth integrated personality, and invest their leisure time, invest their power in community service projects and environment development, and provide them with behavioral and ethical values and prevent them from deviation.

\section{Second aspect - "sports clubs and citizenship values within} Members"

Research sample opinions agreed that citizenship values for sports clubs members are:

I- Belonging : represented in receiving sports teams when returning from tournaments, follow sporting events and news for sports club difference, support teams in all sports leagues, Raise Egyptian flag at the club when winning sports championships and Publish sports teams' achievements.

II-Rights: Rights : represented in : Practicing sport as a fundamental right for every individual in the community, Providing monthly sports programs for all members, Club offers financial support necessary for practicing various sports activities for members, Providing sports activities for handicapped individuals, Provide educational seminars to illustrate sport importance for individual and society.

III- Duties: represented in: Compliance to laws and rules governing sports activity, Legitimacy of local and international sports institutions' decisions, Using legal means to express objection to any injustice faced, Maintain sports facilities (stadiums - lounges ...), Commitment during matches to observe sportsmanship, Respect sports practice values and traditions of in our eastern society, Respect referee's decisions during matches, Maintain stadiums sanctity during sports matches

IV- Community Participation: represented in: Cooperation during sports activities, Attend summer camps annually organized by the club, Volunteering to participate in sporting events organized by the club, Encourage members to community participation through volunteer work, Participation in sports festivals that are calling for a charitable goals, Contribution in spreading sports awareness among community members,

Third aspect - "obstacles that limit the role of sports clubs programs in countering crime" 
Research sample agreed that obstacles represented in: Weakness and lack of qualified human resources needed to implement the necessary programs to protect against crimes, Weakness of media coverage of various programs at sports clubs, lack of coordination and cooperation between sports clubs and Ministry of Youth and Sports and Ministry of Information to curb crimes at sports clubs, and Not focusing on programs that satisfy mental and physical youth desires

\section{Fourth aspect: - " Methods of activating the role of sports clubs programs in countering crime}

Research sample agreed that methods of activation represented in: Provide the necessary financial resources to implement necessary programs for crime prevention, Manipulating media through development of programs which refute imported ideas and suspicious cultures, Make motivational prizes for participants in various programs and activities, and Conducting summer centers programs at activity stops time to exploit the potential of clubs to curb crime

\section{Recommendations}

From results presentation and discussion the following could be recommended:

I- To officials at clubs and Ministry of Youth and Sports, it is necessary to apply the proposed model

II- $\quad$ The proposed model

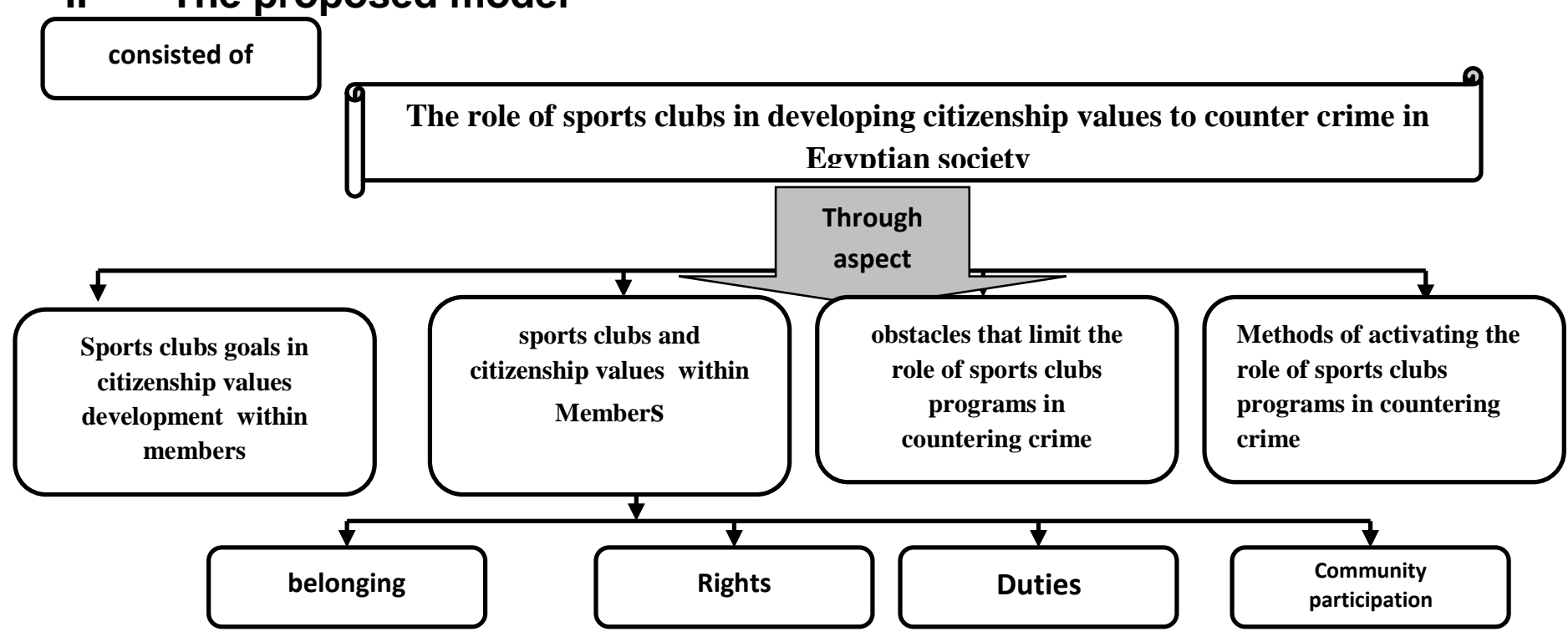

III- To apply the proposed model: it is necessary to be guided by research questionnaire aspects' results as follows: - 


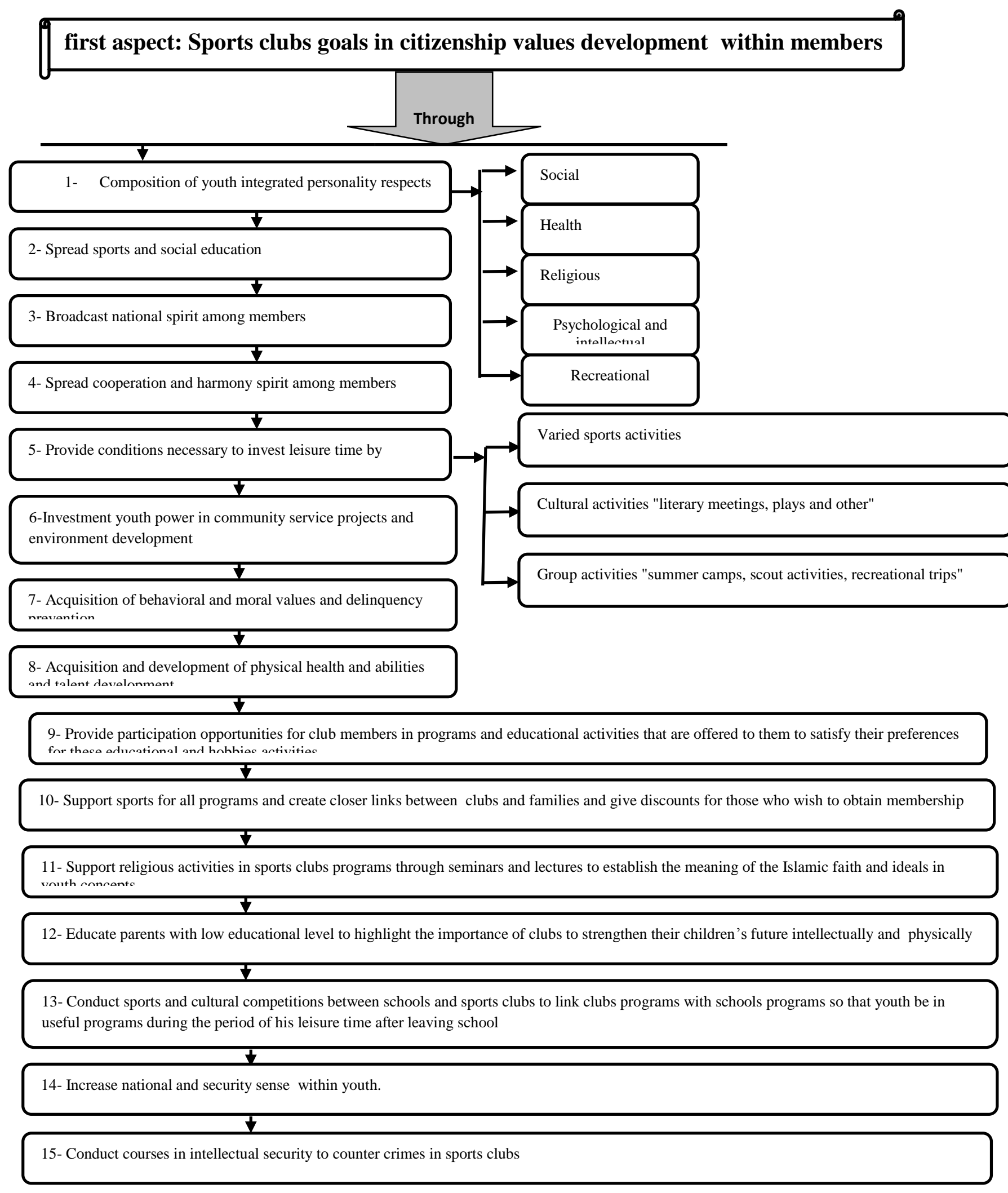




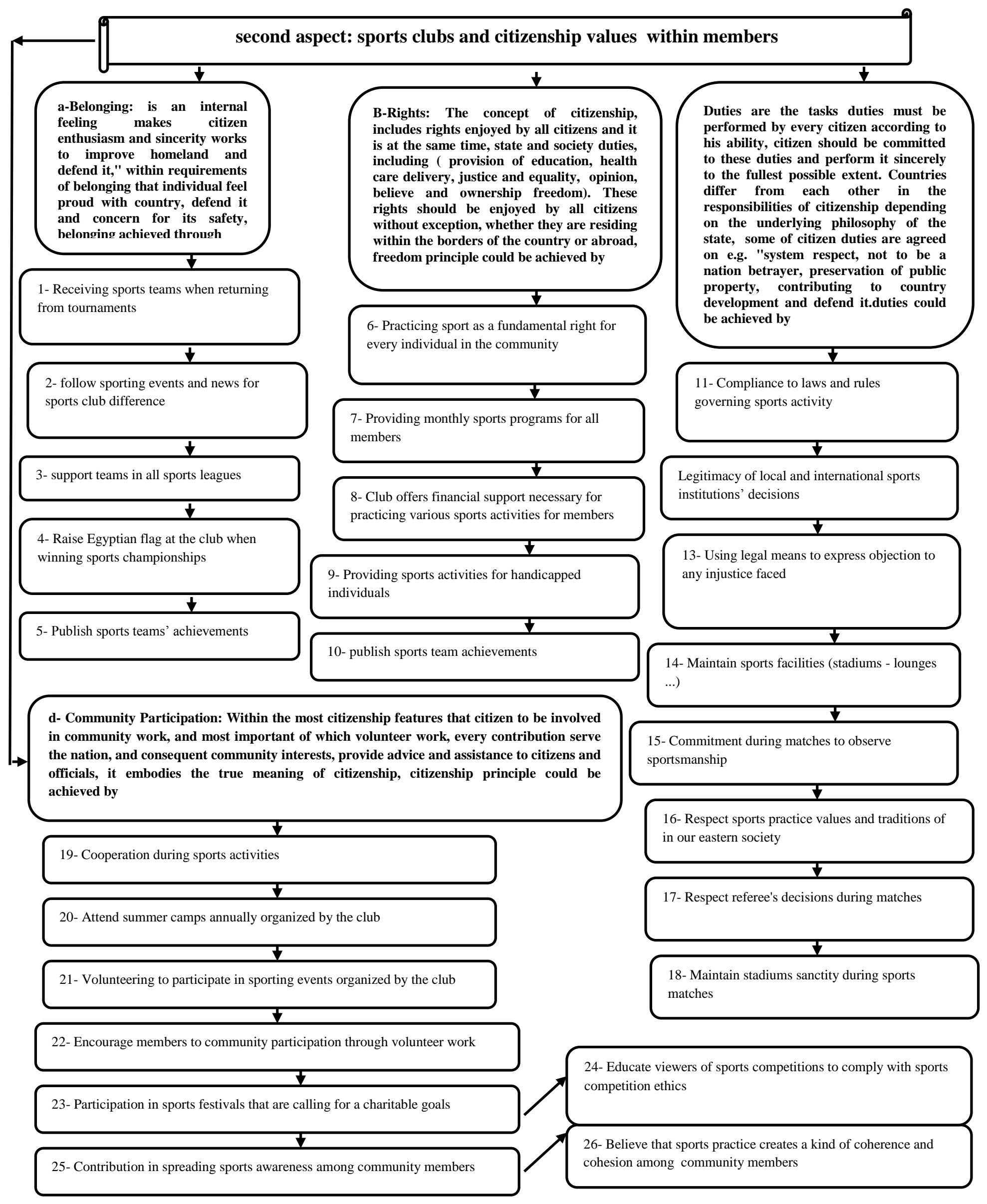


third aspect: Obstacles that limit the role of club programs in countering crime

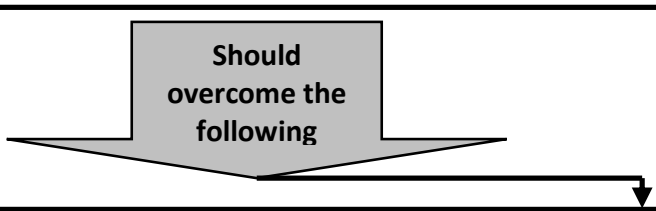

1- Weakness and lack of qualified human resources needed to implement the necessary programs to protect against crimes

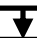

2- lack of material resources needed to implement necessary program for crime prevention at sports clubs

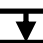

3- Weakness of media coverage of various programs at sports clubs

4- lack of coordination and cooperation between sports clubs and Ministry of Youth and Sports and Ministry of Information to curb crimes at sports clubs

5- Some parents have convictions that youth participation in sports clubs programs is useless

6- Some parents have convictions that youth participation in sports clubs programs is useless

7- Lack of some clubs management interest with programs, especially cultural and social ones

8- Presence of legacy customs and traditions that convey a bad image of sports clubs

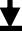

9- Lack of youth participation in program planning led to its weakness

10- No focusing on programs that satisfy mental and physical youth desires

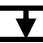

11- Non-evaluation of different programs efficiency

12- Lack of incentives for activities and programs administrators or supervisors.

13- Non-availability of suitable facilities to accommodate youth in clubs such as "theaters, stadiums " 
fourth aspect: Methods of activating the role of sports clubs programs in countering crime

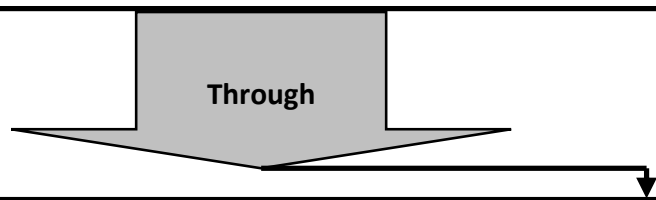

1- provide the necessary financial resources to implement necessary programs for crime prevention

2- coordination between Ministry of Youth and Sports, sports clubs and educational institutions to consolidate moderation

$\checkmark$

3- Manipulating media through development of programs which refute imported ideas and suspicious cultures

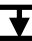

4- Expansion of conducting different programs under the slogan (no for crime)

5- Calling famous persons like "scholars, preachers, writers, celebrities foot ball " in football

7

6- Make motivational prizes for participants in various programs and activities

$\checkmark$

7- Showing the efforts made by clubs in all its programs and cover it at all media

8- Getting help of youth care programs specialists in reducing crime programs

9- Study youth needs and desires between sports clubs

7

10- Benefit from other countries experiences in development clubs programs to reduce crime

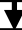

11- activating the role of media center in clubs to show club programs in crime protection and reducing, "extremism - Intellectual deviations"

12- Conducting summer centers programs at activity stops time to exploit the potential of clubs to curb crime

13- exploitation of famous players celebrity players in the awareness programs for crime protection and reduction 
References

Abdel-Moez, Ashraf (1997): Evaluating sports economics at clubs, unpublished PhD thesis, Faculty of Physical Education for Men, Helwan University, Cairo. (in Arabic language)

Abdul-Ghani, Naaman (2014): the role of sport in citizenship education., available

at: http://www.arabworldbooks.com/arabic/namane_sport.htm. (in Arabic language)

Abu-Sheaishea, Khalid Hassan (2005): The role of National Finance in achieving sports activity goals for some major clubs in the Arab Republic of Egypt, unpublished Master Thesis, Faculty of Physical Education for Girls, Alexandria University. (in Arabic language)

Al- Hassania, Said Ali (2005): the role of social values in crime prevention, unpublished Master Thesis, Naif Arab University for Security Sciences, Faculty of Graduate Studies, Riyadh. (in Arabic language)

Al-Abd, Rashid bin Hussein and Al-Nassar, Saleh Abdul Aziz (2007): National Education in schools in Kingdom of Saudi Arabia, a comparative analysis study in light of modern educational trends, thirteenth annual meeting educational work leaders, Faculty of Education, King Saud University. (in Arabic language)

Al-Arabi, Bilal: Values and Social Change (2001): Youth model, Journal of Future Studies, Issue 6, Assiut University, Egypt. (in Arabic language)

Al-Baz, Rashid bin Saad (2007): Community partnership between community institutions and security agencies, "published research", , Arab Gulf States Cooperation Council Secretariat, Riyadh. (in Arabic language)

Aljahni, Ali ben Faiz (2000): Security Media and crime prevention, Naif Arab University for Security Sciences, Riyadh. (in Arabic language)

Al-Khatib; Muhammad ibn Shahat (2006): intellectual deviation and its relationship with national and international security, King Fahd National Library, Riyadh. (in Arabic language)

Al-Mashari, Abdullah bin Saad (2002): Organizational development Obstacles from perspective of senior and middle leadership in Riyadh, Makkah police regions. Unpublished master thesis, , 
Naif Arab University for Security Sciences, Riyadh. (in Arabic language)

Al-Najjar, Said (1999): Universal Declaration of Human Rights in $50^{\text {th }}$ festival, new appeal seminars, issue (37) April, the new appeal Association, Cairo. (in Arabic language)

Alosbae, Mohammed Ibrahim Omar (2000): Security in its total concept and education importance in its composition, Studies and Research Center, Naif Arab University for Security Sciences, Riyadh. (in Arabic Language)

Al-Otaibi, Saif Mashour (1994): Clubs programs and their relationship with youth needs in Riyadh, unpublished Master Thesis, Naif Arab University for Security Sciences, Riyadh. (in Arabic language)

Al-Sissi Abdel Fattah (2014): Arab Republic of Egypt's President statement to the United Nations General Assembly, New York

Behbehani, Khalifa (2004): Management encyclopedia in sports organizations, Faisal Press, $1^{\text {st }}$ ed., Kuwait. (in Arabic language)

Darwish, Kamal al-Din Abdul Baqi, and Abdel-Moez: Ashraf (2000): National Sports Organizations, Friends Library, Cairo. (in Arabic language)

Eley D., and Kirk D. (2002):Developing citizenship through sport- the impact of a sport- based volunteer program on young sport leaders, sport education and society issue 1,2 October.

El-Sabea, Mohamed Tharwat(2005): Evaluation of internal control methods within sports clubs, unpublished Master Thesis, Faculty of Physical Education, Tanta University. (in Arabic language)

Ghalioun, Burhan (1991): Political criticism " religion and the state," Arab Democracy Foundation for Studies and Publishing, Beirut. (in Arabic language)

Hegazi, Mohamed Abdel Aziz (2002): Sports' economic management seminar, Faculty of Commerce, Cairo University, $3^{\text {rd }}$ ed., Cairo University of Press.(in Arabic Language)

Khedr, Latifa Ibrahim (200): the role of education in belonging promoting, published study, $1^{\text {st }}$ ed., books world, Cairo. (in Arabic language)

Leya, Ali (2007): Civil Society "citizenship and human rights issues", $1^{\text {st }}$ ed., Anglo-Egyptian Library, Cairo. (in Arabic language)

MacDonald, L (2003):Traditional Approaches to Citizenship Education Globalization, towards Peace Education Frame Work. A doctorate dissertation Dalhousie University. Canada, 
Mark W., Aoyagi A., Richard H. ,Cox A., Richard T., Mc Guire (2008):

Organizational citizenship behavior in sport relationships with leadership team cohesion, and athlete satisfaction, journal of applied sport psychology volume 20 , issue 1, January.

Ministry of Youth and Sports (2013): sports clubs bylaw. (in Arabic Language)

Moussa, Yusreya Ibrahim (2000_: Relationship between some variables associated with work climate with practicing organizational citizenship behaviors for school administration officials in Alexandria, , Faculty of Physical Education for Girls journal, Alexandria University, (in Arabic language)

Muhanna, Mohamed Nasr(1996): Introduction to Arab national security in changing world, Modern university office, Alexandria. (in Arabic language)

Mustafa, Mahmoud Hassan (2002): Decision-making ability within sports clubs officials, unpublished Master Thesis, Faculty of Physical Education for Men, Helwan University. (in Arabic language)

Podsakoff, N.P., Whiting, S.W., \& Blume B.D., (2009):Individual and organizational level consequences of organizational citizenship behaviors A Meta-analysis, journal of applied psychology, vol. 94 , No. 1.

Qtaify, Ezzedine (2007): The role of school sports activities in good citizenship education, Department of Physical Education, Riyadh University, physical education network and forums, available

at: http://www.abegs.org/aportal/article/showdetails?id-2306. Arabic language)

Raouf, Heba Ezzat (2006): Citizenship between Community ideals and individuality myths, $17^{\text {th }}$ Conference of Political Research, Faculty of Economics and Political Science, Cairo University. (in Arabic language)

Scott Brook (2009): Success Build Good Citizen Basket Philadelphia by U.C.R Researcher, May

www.ahram.org.eg/Al-Ahram-Files/News/128721.aspx, (in Arabic language) 
Yasin, El-Sayed. (2004): Citizenship in globalization era, the Coptic Centre for Social Studies, of citizenship series, Cairo. (in Arabic language) 